\title{
THE REVISED CANADIAN TEST FOR THE EXCLUSION OF UNCONSTITUTIONALLY OBTAINED EVIDENCE
}

\author{
BC Naudé \\ Bluris LLB LLD \\ Professor of Law \\ University of South Africa (UNISA)
}

\section{SUMMARY}

Although South African courts have relied on Canadian law to interpret section 35(5) of the Constitution, they have also been hesitant to do so, since the previous Canadian approach clearly had its shortcomings. The Canadian Supreme Court's decision in $R \vee$ Grant has now addressed these problems by putting forward an approach that is less rigid and more simplistic to apply. The new test reflects properly the main motivation behind a constitutionally entrenched exclusionary rule and thereby provides a sound theoretical basis for the application of such a rule. Because their new approach has brought the South African and Canadian tests closer together, more stands to be gained from future Canadian decisions in this regard. Perhaps the most important aspect of the Grant decision is that it shows why it is unnecessary to treat the two legs of the South African rule as separate tests. There should in principle be only one test: namely whether the admission of unconstitutionally obtained evidence would be detrimental to the administration of justice.

\section{INTRODUCTION}

Canadian jurisprudence has influenced the way in which our courts have interpreted the different elements in section 35(5) of the Constitution. ${ }^{1}$ This is understandable in view of the similarities between section 35(5) and section 24(2) of the Canadian Charter of Rights and Freedoms. ${ }^{2}$ It has, however,

Act 108 of 1996. S 35(5) states: "Evidence obtained in a manner that violates any right in the Bill of Rights must be excluded if the admission of that evidence would render the trial unfair or otherwise be detrimental to the administration of justice."

2 See generally Schwikkard and Van der Merwe Principles of Evidence 3ed (2009) 214. The Canadian rule states: "24(1) Anyone whose rights or freedoms, as guaranteed by this Charter, have been infringed or denied may apply to a court of competent jurisdiction to obtain such remedy as the court considers appropriate and just in the circumstances. 24(2) Where, in proceedings under subsection (1), a court concludes that evidence was obtained in a manner that infringed or denied any rights or freedoms guaranteed by this Charter, the evidence shall be excluded if it is established that, having regard to all the circumstances, the admission of it in the proceedings would bring the administration of justice in disrepute.' These two sections are similar to s 38 and s 35(5) of the South African Bill of Rights respectively. Schwikkard and Van der Merwe 214 note the main differences between s $35(5)$ of the South African Constitution and s 24(2) of the Canadian Charter of Rights and 
been remarked that care should be taken in this regard, since Canadian courts have not only given a narrow interpretation of some aspects of their test, but many of their ideas have been adopted from the USA where there is no constitutionally entrenched exclusionary rule and where aggressive exclusion is at the order of the day. ${ }^{3}$

Concerns about the application of the Canadian test have now been vindicated by the recent judgment by the Canadian Supreme Court in $R v$ Grant. $^{4}$ This judgment has revisited the test for the exclusion of unconstitutionally obtained evidence in Canada and has brought the application of the Canadian test closer to that of the South African test. It is submitted that more now stands to be gained from future Canadian decisions in this regard.

The new Canadian test has moved away from the idea of compartmentalizing certain aspects of a constitutionally entrenched exclusionary rule by placing a proper emphasis on the main motivation for having an exclusionary rule in the first place. This shows that it is unnecessary to consider the two legs in the South African rule as separate tests. There should in principle only be one test: namely whether the admission of certain evidence would be detrimental to the administration of justice, but fair trial principles necessarily provide a big part of the answer to this question.

\section{2

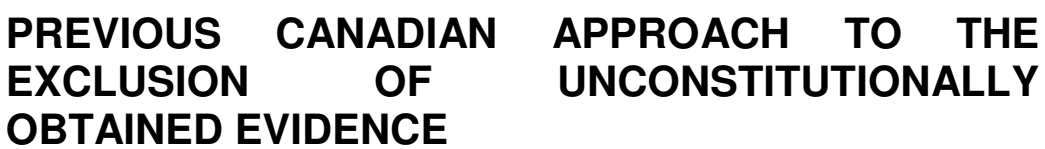

A brief look at how Canadian courts previously interpreted the elements of their test is necessary to fully appreciate the changes brought about by $R v$ Grant. ${ }^{5}$ Once a causal relationship between a Charter violation and the

Freedoms: "[S] 35(5) makes specific reference to a fair trial, whereas s 24(2) does not (and had to be read into s 24(2) by the Supreme Court of Canada ... ; s 35(5) used the criterion "detrimental to the administration of justice", whereas s 24(2) created the criterion "bringing the administration of justice into disrepute" which, it is submitted, is a broader test than "detrimental to the administration of justice" ... ; the words "if it is established that" in s 24(2) do not appear in s 35(5) ...; the words "having regard to all the circumstances" appear in $s$ 24(2) but not in s 35(5) - a difference which is of no consequence as a court which interprets and applies $S 35(5)$ must of necessity take into account all the circumstances.'

3 In S v Pillay 20042 SACR 419 (SCA) 444j-445b Scott JA cautions in a minority judgment that: "It follows that Canadian decisions can provide a useful guide when interpreting s 35(5) of our Constitution. Nonetheless, the greatest caution must be exercised when transporting those decisions to the South African context. (See in this regard the remarks of Ackermann $J$ in Ferreira $v$ Levin No and Others; Vryenhoek and Others v Powell NO and Others 1996 (1) SA 984 (CC) ... at 1065B-D ... It should be borne in mind that by reason of the wide powers of the Canadian Supreme Court to order a retrial, a decision by that Court to exclude evidence is less likely to result in the acquittal of a guilty person than a similar exclusion in South Africa." (See Dressler \& Michaels Understanding Criminal Procedure 4ed (2006) 365 et cet; and Norton "The Exclusionary Rule Reconsidered: Restoring The Status Quo Ante" 199833 WakeForestLRev 261263 for a thorough discussion of the origins and evolution of the American exclusionary rule.)

4 See $R v$ Grant (2009) SCC 32. (This judgment was delivered on 17/7/2009 and is available through www.scc-csc.gc.ca.)

5 Ibid. 
obtaining of evidence was established, it was up to the court to decide whether, in view of "all the circumstances", the challenged evidence "would bring the administration of justice into disrepute". ${ }^{6}$ In exercising a discretion, the courts were directed to consider three groups of factors: ${ }^{7}$ the first group dealt with factors affecting the right to a fair trial, the second group with factors relevant to the seriousness of a Charter violation and the third group with factors concerning the effect that exclusion of the challenged evidence would have on the repute of the administration of justice. ${ }^{8}$

\section{The first group of factors in section 24(2): Factors affecting the right to a fair trial}

The criticism against the application of the Canadian exclusionary rule was primarily directed at the way in which the first group of factors, namely those dealing with the right to a fair trail, was supposed to be approached. In this context, trial fairness contains the notion that it is fundamentally unfair to use evidence that was created by the accused. Such evidence would undermine the presumption of innocence and the accused's privilege against selfincrimination at trial. ${ }^{9}$

A full exposition of the previous approach to the fair trial requirement in Canada (for purposes of exclusion of evidence) is given by the Canadian Supreme Court in $R v$ Stillman. ${ }^{10}$ Firstly, the challenged evidence must be classified as "non-conscriptive" or "conscriptive". ${ }^{11}$ The court states: ${ }^{12}$

"The crucial element which distinguishes non-conscriptive evidence from conscriptive evidence is not whether the evidence may be characterized as 'real' or not. Rather, it is whether the accused was compelled to make a statement or provide a bodily substance in violation of the Charter. Where the accused, as a result of a breach of the Charter, is compelled or conscripted to provide a bodily substance to the state, this evidence will be of a conscriptive nature, despite the fact that it may also be 'real' evidence. Therefore, it may be more accurate to describe evidence found without any participation of the accused, such as the murder weapon found at the scene of the crime, or drugs found in a dwelling house, simply as non-conscriptive evidence; its status as 'real' evidence, simpliciter, is irrelevant to the s 24(2) inquiry."

See $R v$ Collins 19871 SCR 265 par 35.

7 See $R v$ Collins supra par 36-39. Although Lamer $\mathrm{J}$ noted that these categories were merely a "matter of personal preference", they became the governing test for section 24(2).

8 See Schwikkard and Van der Merwe 201-205 for a discussion of these factors.

9 See $R v$ Collins supra par 37.

10971 SCR 607 (see from par 72).

11 See the trial fairness summary from par 112 .

12 Par 77.

13 This approach was in contrast to the previous decision by the Canadian Supreme Court in $R$ $v$ Collins supra par 37 where the court noted about the fair trial requirement: "It is clear to me that the factors relevant to this determination will include the nature of the evidence obtained as a result of the violation and the nature of the right violated and not so much the manner in which the right was violated. Real evidence that was obtained in a manner that violated the Charter will rarely operate unfairly for that reason alone. The real evidence existed irrespective of the violation of the Charter and its use does not render the trial unfair. However, the situation is very different with respect to cases where, after a violation of the Charter, the accused is conscripted against himself through a confession or other evidence 
The court noted that the admission of non-conscriptive evidence will rarely operate to render the trial unfair and the court should move on to consider the other factors that make up the test for exclusion. ${ }^{14}$ If the evidence is found to be conscriptive, the court must then consider whether admission of the evidence would render the trial unfair. Conscriptive evidence refers to "self-incriminating evidence in the form of statements or bodily substances conscripted from the accused in violation of the Charter and evidence derived from unlawfully conscripted statements". ${ }^{15}$ The admission of such evidence will, as a general rule, render the trial unfair. However, if it can be shown (on a balance of probabilities) that the impugned evidence "would have been discovered in the absence of the unlawful conscription of the accused," ${ }^{16}$ admission of the conscriptive evidence will not render the trial unfair. The court noted that there are two principle grounds upon which it can be shown that the evidence would have been discovered absent a Charter violation: ${ }^{17}$

"(a) if the evidence would have been obtained, in any event, from an independent source; in other words, there were alternative nonconscriptive means by which the police would have seized the evidence and the Crown has established, on a balance of probabilities, that the police would have availed themselves of those means ... or

(b) if the evidence would inevitably have been discovered ..."18

A finding of either of these two grounds means that the admission of the evidence will not render the trial unfair and the court must proceed to consider the other elements of the test for exclusion (the seriousness of the Charter breach and the impact of exclusion on the repute of the administration of justice).

An important aspect of the Stillman decision, is the finding that the privilege against self-incrimination is not confined to testimonial utterances or communications, but that it extends to real evidence emanating from an accused, such as hair and blood samples. ${ }^{19}$ This finding changed the Supreme Court's previous approach that was laid down in $R v$ Collins. ${ }^{20}$ In

emanating from him. The use of such evidence would render the trial unfair, for it did not exist prior to the violation, and it strikes at one of the fundamental tenets of a fair trial, the right against self-incrimination."

14 Par 74

15 Par 102.

16 Ibid.

17 Par 116. (See from par 103).

18 See generally Naudé "The Inclusion of Inevitably Discoverable Evidence" 20082 SACJ 168 for a discussion of the meaning and difference between the concepts of "an independent source" and inevitable discovery.

19 The court states at par 86 that: "It has, for a great many years, been considered unfair and indeed unjust to seek to convict on the basis of a compelled statement or confession. If it was obtained as a result of a breach of the Charter its admission would generally tend to render the trial unfair. This is so because the compelled production of bodily parts or substances is just as great an invasion of the essence of the person as is a compelled conscripted statement. The unauthorized use of a person's body or bodily substances is just as much compelled 'testimony' that could render the trial unfair as is a compelled statement."

$20 R v$ Collins supra was confirmed in $R v$ Jacoy 19882 SCR 548. 
that case it was stated that, ${ }^{21}$ for purpose of the trial fairness element in section 24(2), there is a distinction between a situation where real evidence was obtained as a result of a constitutional violation and the situation where, after a violation of a constitutional right, the accused was conscripted against himself through a confession or other evidence emanating from him. In the latter situation, the admission of the evidence would render the trial unfair, since it did not pre-exist the violation and its admission would strongly undermine the right against self-incrimination. Where real evidence is unconstitutionally obtained, however, the accused is not conscripted against himself and the fact that the evidence was unconstitutionally obtained, will rarely cause the trial to be unfair for that reason alone. This is because the real evidence not only pre-existed the constitutional violation, but also existed irrespective of the violation. Such evidence therefore has an independent existence and usually possesses an "objective reliability". $22 \mathrm{v}$ Collins therefore adhered to the distinction between self-incriminating testimonial communications and incriminating non-communicative real evidence obtained from the body of the accused. Unconstitutionally obtained non-communicative real evidence will therefore not affect the fairness of a trial in the sense of being an infringement involving self-incrimination. Whether such evidence aught to be excluded will rather depend on the third group of factors: those concerning the effect that exclusion of the challenged evidence would have on the repute of the administration of justice. ${ }^{23}$

The Stillman modification was justifiably criticised by commentators. ${ }^{24}$ Schwikkard and Van der Merwe ${ }^{25}$ describe it as "totally unnecessary and somewhat artificial". They point out that the majority in $R v$ Stillman conceded that even without a reformulation of the trial fairness branch of the test in $R v$ Collins, exclusion of the challenged evidence would in any event have resulted, because it can be said that the unconstitutional bodily searches in $R v$ Stillman, were so unreasonable and serious that to admit the evidence thereby obtained, would also have brought the administration of justice into disrepute. The majority in $R v$ Stillman did not see, however, this approach as recognising the innate dignity of the individual, based upon

\footnotetext{
Par 37.

Compare S v M 20022 SACR 411 (SCA) par 31.

${ }^{23}$ For an application of the Collins test in South Africa - see $S v$ Mkhize 19992 SACR 632 (W) 637g-h; and S v R2000 1 SACR 33 (W) 40g-41d.

24 In $R v$ Grant supra par 101 the majority notes the main points of criticism: "Stillman has been criticized for casting the flexible 'in all the circumstances' test prescribed by s. 24(2) into a straightjacket that determines admissibility solely on the basis of the evidence's conscriptive character rather than all the circumstances; for inappropriately erasing distinctions between testimonial and real evidence; and for producing anomalous results in some situations: see, e.g., Burlingham, per L'Heureux-Dubé J.; R. v. Schedel (2003), 175 C.C.C. (3d) 193 (B.C.C.A.), at paras. 67-72, per Esson J.A.; D.M. Paciocco, 'Stillman, Disproportion and the Fair Trial Dichotomy under Section 24(2)' (1997), 2 Can. Crim. L.R. 163; R. Mahoney, 'Problems with the Current Approach to s. 24(2) of the Charter: An Inevitable Discovery' (1999), 42 Crim.L.Q. 443; S. Penney, 'Taking Deterrence Seriously: Excluding Unconstitutionally Obtained Evidence Under Section 24(2) of the Charter' (2004), 49 McGill L.J. 105; D. Stuart, Charter Justice in Canadian Criminal Law (4th ed. 2005), at p. 581." (See par 102-106 where the court discusses these issues).

25240.
} 
the integrity and sanctity of the body. ${ }^{26}$ Schwikkard and Van der Merwe, ${ }^{27}$ however, point out that the second leg of the test in section $35(5)^{28}$ caters not only for the exclusion of unconstitutionally obtained real evidence of bodily samples, but can also be used to protect the constitutional rights to freedom and security of the person, dignity and privacy. ${ }^{29}$ They concede that the Constitutional Court's description of the right to a fair trial is so wide that a court might exclude unconstitutionally obtained real evidence like bodily samples in terms thereof, but this should then be done without expanding the ambit of the privilege against self-incrimination to include bodily samples. It is therefore unnecessary to place unconstitutionally obtained bodily samples on the same footing as conscriptive testimonial communications emanating from the accused.

A different approach to the fair trial requirement is now stipulated by the Supreme Court of Canada in $R v$ Grant. ${ }^{30}$ As a start, the fair trial requirement is no longer a cornerstone of the test in section 24(2). This is not only because of the criticism against the previous application of the requirement, but also because of the uncertainty that surrounds the meaning of the right to a fair trial under Canadian law. ${ }^{31}$

\section{The second group of factors in section 24(2): Factors relevant to the seriousness of a violation}

In $R v$ Collins $^{32}$ Lamer $\mathrm{J}$ gives an overview of the factors that are relevant when considering the seriousness of a particular violation:

"As Le Dain J. wrote in Therens, at p. 652:

'The relative seriousness of the constitutional violation has been assessed in the light of whether it was committed in good faith, or was inadvertent or of a merely technical nature, or whether it was deliberate, wilful or flagrant. Another relevant consideration is whether the action which constituted the constitutional violation was motivated

See $R v$ Stillman supra par 86 .

2724.

28 See the discussion below under "The second leg of the test in s 35(5): Whether admission would be detrimental to the administration of justice". The second leg of the South African test essentially contains the same wording as the Canadian test - see fn 1 above.

29 These rights are guaranteed in ss 12, 10 and 14 of the Constitution 108 of 1996.

30 Supra - see the discussion below under "Revisited Canadian approach to the exclusion of unconstitutionally obtained evidence".

${ }^{31}$ In $R v$ Grant supra par 207 Deschamps $\mathrm{J}$ remarks (in a minority judgment): "Trial fairness is sometimes defined narrowly and sometimes more broadly. Defined narrowly, it concerns solely the reliability of the evidence. More broadly, trial fairness corresponds to 'courtroom fairness' ... In the latter sense, fairness is related to the concept of 'conscriptive evidence'. Its purpose is to safeguard certain fundamental rights of the accused at trial, such as the right against self-incrimination. This interpretation is essentially the same as the one in $R v$ Stillman ... Finally, trial fairness has been defined very broadly by certain commentators and in certain judgments ... According to this approach, any use of evidence obtained in violation of constitutional rights is - regardless of the quality of the evidence (reliable, conscriptive, derivative etc.) - a breach of trial fairness. It is clear that, although the concept of fairness seems to go hand in hand with any system of justice worthy of that name, it is not precise enough to serve as a reliable guide."

32 Supra par 38. 
by urgency or necessity to prevent the loss or destruction of the evidence.'

I should add that the availability of other investigatory techniques and the fact that the evidence could have been obtained without the violation of the Charter tend to render the Charter violation more serious. We are considering the actual conduct of the authorities and the evidence must not be admitted on the basis that they could have proceeded otherwise and obtained the evidence properly. In fact, their failure to proceed properly when that option was open to them tends to indicate a blatant disregard for the Charter, which is a factor supporting the exclusion of the evidence."

Whether any factor in this group was present is a fact-specific determination and since they are clearly important for an evaluation in terms of section 24(2), no criticism can be brought in against their relevance. As will be seen below, the seriousness of a violation is still one of the central factors to be considered in a section 24(2) application.

\section{The third group of factors in section 24(2): Factors concerning the effect of exclusion on the repute of the administration of justice}

This group of factors was seen as a consideration that would support a conclusion that a particular violation was not sufficiently serious to justify exclusion in a particular case. This category of factors in effect provided a ground for the admission of unconstitutionally obtained evidence. Some commentators questioned the applicability of this group of factors, ${ }^{33}$ but it is submitted that $R v$ Grant $^{34}$ has now placed it into proper perspective and that it is indeed a useful consideration in a section 24(2) analyses.

\section{THE REVISED CANADIAN APPROACH TO THE EXCLUSION OF UNCONSTITUTIONALLY OBTAINED EVIDENCE}

\section{General}

In $R v \operatorname{Grant}^{36}$ the Supreme Court of Canada inter alia revised the framework for determining whether unconstitutionally obtained evidence must be excluded. This came about because of the fact that the existing framework was difficult to apply and produced unsatisfactory results. ${ }^{37}$ The "all-but automatic" exclusionary rule for non-discoverable conscriptive evidence not only broadened the category of conscriptive evidence, but also increased its importance to the final decision on admissibility. This first of all went against

\footnotetext{
See, eg, Sophinka, Lederman and Bryant The Law of Evidence in Canada (1992) 424.

Supra.

35 See the discussion below under "Society's interest in the adjudication of the case on its merits".

36 Supra.

37 See par 60.
} 
the requirement that the court must consider "all the circumstances" when determining admissibility. ${ }^{38}$ The majority in $R v$ Grant notes: ${ }^{39}$

"The underlying assumption that the use of conscriptive evidence always, or almost always, renders the trial unfair is also open to challenge. In other contexts, the Court has recognized that a fair trial 'is one which satisfies the public interest in getting to the truth, while preserving basic procedural fairness to the accused': $R v$ Harrer, [1995] 3 S.C.R. 562, at para. 45. It is difficult to reconcile trial fairness as a multifaceted and contextual concept with a near-automatic presumption that admission of a broad class of evidence will render a trial unfair, regardless of the circumstances in which it was obtained. In our view, trial fairness is better conceived as an overarching systemic goal than as a distinct stage of the s. 24(2) analysis."

In $R v$ Grant the accused appealed his conviction on a number of firearm offences in connection with a gun seized by the police during an encounter on the streets of Toronto. The appellant had walked past two plainclothes police officers in a manner that they considered suspicious. They asked a uniformed officer, one Gomes, to stop the appellant. Gomes stood in the appellant's way, told him to keep his hands in front of him asked him what was going on, and asked him for his name and address. After the appellant produced some identification, the two plainclothes officers arrived, showed the accused their badges, and stood behind Gomes. Whenever the appellant moved, Gomes maintained his position relative to the appellant. Gomes asked the appellant whether he had ever been arrested, and the appellant replied that he had been in some trouble before. Gomes then asked the appellant whether "he had anything he shouldn't". The appellant eventually admitted to having a small amount of marihuana. Gomes did not arrest the appellant at this moment, but the prosecution conceded that the appellant was detained at this point. Gomes then asked the appellant whether there was anything else, upon which the appellant admitted that he had a firearm. The accused was then arrested and a loaded revolver was seized.

Two important questions had to be answered on the appeal: that is, whether evidence of the gun was obtained in breach of the appellant's rights, ${ }^{40}$ and if so, whether the evidence should have been excluded in terms

38 See $R v$ Collins supra par 35. (Also see $R v$ Grant supra par 60 where the majority notes that the test in s 24(2) is "broad and imprecise").

39 Par 65. (The majority judgment was delivered by McLachlin CJ and Charron J).

40 This essentially entailed a consideration of the meaning of "detention". (A full discussion of this issue is beyond the scope of this article and an opinion on this issue has already been expressed elsewhere - see Naudé "A Suspects Right to be Informed" 20092 SAPublicLaw 312 for a discussion of the decision by the Ontario Court of Appeal in $R v$ Grant (2006) 209 CCC (3d) 250 (Ont CA)). After considering the meaning of "detention" the majority in $R v$ Grant 2009 SCC 32 par 45 comes to the conclusion (which is fully supported): "In summary, we conclude as follows: 1 . Detention under ss. 9 and 10 of the Charter refers to a suspension of the individual's liberty interest by a significant physical or psychological restraint. Psychological detention is established either where the individual has a legal obligation to comply with the restrictive request or demand, or a reasonable person would conclude by reason of the state conduct that he or she had no choice but to comply. 2. In cases where there is no physical restraint or legal obligation, it may not be clear whether a person has been detained. To determine whether the reasonable person in the individual's circumstances would conclude that he or she had been deprived by the state of the liberty of choice, the court may consider, inter alia, the following factors: a) The circumstances giving rise to the encounter as would reasonably be perceived by the individual: whether the police 
of section 24(2) of the Canadian Charter of Rights and Freedoms. After coming to the conclusion that the relevant evidence was obtained in breach of the appellant's rights, ${ }^{41}$ the court turned to the issue of whether the evidence should have been excluded. ${ }^{42}$

In setting out a revised approach to section 24(2), the court firstly stated that the words in section 24(2) capture its purpose: to maintain the repute of the administration of justice. ${ }^{43}$ This includes maintaining the rule of law and upholding Charter rights in the justice system as a whole. The court noted: ${ }^{44}$

"The phrase 'bring the administration of justice into disrepute' must be understood in the long-term sense of maintaining the integrity of, and public confidence in, the justice system. Exclusion of evidence resulting in an acquittal may provoke immediate criticism. But s. 24(2) does not focus on immediate reaction to the individual case. Rather, it looks to whether the overall repute of the justice system, viewed in the long term, will be adversely affected by admission of the evidence. The inquiry is objective. It asks whether a reasonable person, informed of all relevant circumstances and the values underlying the Charter, would conclude that the admission of the evidence would bring the administration of justice into disrepute."

The court further points out that the focus of section 24(2) is not only longterm, but also prospective. ${ }^{46}$ It firstly tries to limit the damage to the administration of justice already caused by the constitutional violation. The focus of section 24(2) is also societal in the sense that its purpose is not to punish the police or provide compensation to the accused, but at systemic concerns: it is about the "broad impact of admission of the evidence on the long-term repute of the justice system".

were providing general assistance; maintaining general order; making general inquiries regarding particular occurrence; or, singling out the individual for focussed investigation. b) The nature of the police conduct, including the language used; the use of physical contact; the place where the interaction occurred; the presence of others; and the duration of the encounter. c) The particular characteristics or circumstances of the individual where relevant, including age; physical stature; minority status; level of sophistication."

See from par 45.

42 See from par 59.

43 Par 67.

44 Par 68.

45 This view takes after another landmark decision on the exclusion of unconstitutionally obtained evidence by the Supreme Court of Canada in $R v$ Collins supra, where it was stated (par 33-34): "The approach I adopt may be put figuratively in terms of the reasonable person test proposed by Professor Yves-Marie Morisette ... In applying s 24(2), he suggested that the relevant question is: 'Would the admission of the evidence bring the administration of justice into disrepute in the eyes of the reasonable man, dispassionate and fully apprised of the circumstances of the case?' The reasonable person is usually the average person in the community, but only when the community's current mood is reasonable ... The decision is not left to the untramelled discretion of the judge. In practice, as Professor Morisette wrote ... the reasonable person test is there to require of judges that they 'concentrate on what they do best: finding within themselves, with cautiousness and impartiality, a basis for their own decisions, articulating their reasons carefully and accepting review by a higher court where it occurs'. It serves as a reminder to each individual judge that his discretion is grounded in community values, and, in particular, long-term community values. He should not render a decision that would be unacceptable to the community when that community is not being wrought with passion or otherwise under passing stress due to current events."

46 Par 69-70. 
The court is of the opinion that a court must, when considering an application for exclusion in terms of section 24(2), assess and balance the effect of admitting the evidence on society's confidence in the justice system. ${ }^{47}$ In this regard the following factors must be considered:

"(1) the seriousness of the Charter-infringing state conduct (admission may send the message the justice system condones serious state misconduct), (2) the impact of the breach on the Charter-protected interests of the accused (admission may send the message that individual rights count for little), and (3) society's interest in the adjudication of the case on its merits. The court's role on a s. 24(2) application is to balance the assessments under each of these lines of inquiry to determine whether, considering all the circumstances, admission of the evidence would bring the administration of justice into disrepute. These concerns, while not precisely tracking the categories of considerations set out in Collins, capture the factors relevant to the s. 24(2) determination as enunciated in Collins and subsequent jurisprudence."

\section{The seriousness of the Charter-infringing state conduct}

The first avenue of inquiry requires a court to decide whether admission would send a message to the public that the courts condone state deviation from the rule of law by failing to distance themselves from the outcome of that unlawful conduct. The court notes that the more severe or deliberate the state conduct that led to the violation, the greater the need for the courts to distance themselves from that conduct. ${ }^{48}$ In such circumstances exclusion is necessary to preserve public confidence in and ensure state adherence to the rule of law. The court goes on to explain that this necessarily involves an evaluation of the seriousness of the conduct that caused the violation, but that the concern here is not to punish the police. The preservation of public confidence in the rule of law and its processes is paramount and must be weighed against the seriousness of the conduct by the very authorities whom the rule of law requires to uphold constitutionally guaranteed rights.

Evidence obtained through inadvertent or minor violations of the Charter will consequently hardly undermine public confidence in the rule of law, but evidence obtained through a wilful or flagrant disregard of Charter rights will inevitably impact on public confidence in the rule of law and will point to exclusion. The court notes that extenuating circumstances, for example the need to prevent the disappearance of evidence, may attenuate the seriousness of a violation. ${ }^{49}$ Good faith on the part of the police will likewise reduce the need for the court to distance itself from the police conduct, but negligence or wilful blindness cannot be seen as good faith.

\section{The impact on the Charter-protected interests of the accused}

The second avenue of inquiry looks at the extent to which the violation actually undermined the interests protected by the right violated. The impact

\footnotetext{
$47 \quad$ See par 71.

48 Par 72.

49 Par 75
} 
of a particular violation may only be technical or fleeting, but it can also be "profoundly intrusive". 50 The court points out that it is important to look at the interests engaged by the infringed right and to consider the degree to which the violation impacted on those interests. ${ }^{51}$

\section{Society's interest in the adjudication of the case on its merits}

The third line of inquiry asks whether the "truth-seeking function of the criminal trial process would be better served by admission of the evidence, or by its exclusion" ${ }^{52}$ It essentially means that a court should not only consider the negative impact of admission of the evidence on the repute of the administration of justice, but also the impact of failing to admit the impugned evidence. The court notes, however, that the concern for truthseeking is only one of the considerations and the view that reliable evidence is admissible regardless of how it was obtained is inconsistent with the Charter's affirmation of rights. Such a notion is also inconsistent with the wording of section 24(2) that requires an inquiry into all the circumstances, and not just into the reliability of the evidence. ${ }^{53}$ The reliability of the evidence remains, however, an important factor to consider. The court notes: ${ }^{54}$

"The fact that evidence obtained in breach of the Charter may facilitate the discovery of the truth and the adjudication of a case on its merits must therefore be weighed against factors pointing to exclusion, in order to 'balance the interests of truth with the integrity of the justice system': Mann, at para. 57, per lacobucci J. The court must ask 'whether the vindication of the specific Charter violation through the exclusion of evidence extracts too great a toll on the truth-seeking goal of the criminal trial': $R$. v. Kitaitchik (2002), 166 C.C.C.

(3d) 14 (Ont. C.A.), at para. 47, per Doherty J.A."

An important issue under this inquiry is the question of whether a court should consider the seriousness of the offence as a factor favouring inclusion. ${ }^{55}$ The court points out that this consideration has a potential to cut both ways. Although a failure to prosecute a serious charge effectively may have an immediate impact on the public's view of the criminal justice system, it is the long-term repute of the justice system that is the focus of section 24(2). The court remarks: ${ }^{56}$

"As pointed out in Burlingham, the goals furthered by s. 24(2) 'operate independently of the type of crime for which the individual stands accused' (para. 51). And as Lamer J. observed in Collins, "[t]he Charter is designed to protect the accused from the majority, so the enforcement of the Charter must not be left to the majority" (p. 282). The short-term public clamour for a conviction in a particular case must not deafen the s. 24(2) judge to the

\footnotetext{
50 See par 76.

51 Par 77

52 See par 79.

53 See par 80.

54 Par 82.

55 See par 84.

56 Par 84.
} 
longer-term repute of the administration of justice. Moreover, while the public has a heightened interest in seeing a determination on the merits where the offence charged is serious, it also has a vital interest in having a justice system that is above reproach, particularly where the penal stakes for the accused are high."

The court emphasizes that the above three lines of inquiry reflect the notion that a court must consider "all the circumstances" and that after having done this, that the court must then determine, whether, on balance, the admission of the evidence would bring the administration of justice into disrepute. ${ }^{57}$ The court points out that although no overarching rule determines how the balance should be struck, patterns may emerge with respect to particular types of evidence, and that these patterns serve as guides to future section 24(2) inquiries. The court next considers the application of the stated test to different kinds of evidence.

\section{Statements by the accused}

As far as unconstitutionally obtained statements is concerned, the court notes that the three lines of inquiry support the presumptive general, although not automatic, exclusion of such statements. ${ }^{58}$ In summary the court concludes that the heightened concern with proper police conduct in obtaining statements from suspects and the importance of the protected interests will in most cases favour exclusion of unconstitutionally obtained statements. ${ }^{59}$ The court is further of the opinion that the third factor may be attenuated by a lack of reliability and that this, together with the historic tendency to treat statements differently from other evidence, explains why such evidence tends to be excluded.

\section{Bodily evidence}

As was seen from the discussion above, the majority in $R v$ Stillman ${ }^{60}$ held that evidence taken from the body of the accused, such as DNA evidence, is "conscriptive" and that its admission would affect trial fairness. This resulted in an almost automatic exclusionary rule for bodily evidence. After considering the various grounds of criticism against the rule in $R v$ Stillman, ${ }^{61}$ the court came to the conclusion that the approach in $R v$ Stillman should be replaced by a flexible test that takes all the circumstances into account. As is the case with other types of evidence, regard should be had to the seriousness of the police conduct, the impact of the violation on the protected interests of the accused, and the value of the trial on the merits. ${ }^{62}$

\footnotetext{
Par 85.

See from par 89.

Par 98.

Supra.

See from par 101.

See par 107.
} 


\section{Non-bodily physical evidence}

Non-bodily physical evidence refers to evidence unconstitutionally obtained from the accused during a search of for example his body, house or place of business. The court points out that the new three-legged test will also apply to this type of evidence. ${ }^{63}$ In terms of the first line of inquiry much will therefore depend upon whether the police's conduct as "deliberate or egregious". As far as the second inquiry is concerned, the court will most of the time have to determine the extent to which the right to privacy was infringed, ${ }^{64}$ and an answer to the third line of inquiry will depend on the facts of the case.

\section{Derivative evidence}

As was seen from the discussion above, derivative evidence refers to physical or real evidence discovered as a result of an unlawfully obtained statement. After rejecting the notion that discoverability should be the determinative factor for admissibility of such evidence, ${ }^{65}$ the court comes to the conclusion that in order to determine whether the admission of derivative evidence would bring the administration of justice into disrepute, courts must also apply the usual three avenues of inquiry, taking into account the selfincriminatory origin of the evidence, as well as its status as real evidence. ${ }^{66}$

\section{The court's decision on exclusion}

The court pointed out that because the gun was discovered as a result of statements taken in violation of the appellant's rights, it is derivative evidence. The usual three lines of inquiry must be applied in view of all the circumstances of the case, including the arbitrary detention of the appellant and the violation of his right to counsel. ${ }^{67}$

As far as the seriousness of the violation is concerned, the court pointed out that the police conduct was not abusive, and although the police went too far in detaining the accused and asking him questions, their mistake can be understood and was not made in bad faith. ${ }^{68}$ Nor was their conduct in violating the Charter deliberate or egregious. The court concludes that admitting the evidence would not undermine public confidence in the rule of

63 See par 112.

64 The court notes par 114: "The question is how serious the Charter breach impacted on these interests. For instance, an unjustified strip search or body cavity search is demeaning to the suspect's human dignity and will be viewed as extremely serious on that account: $R$. $v$. Simmons ... The fact that the evidence thereby obtained is not itself a bodily sample cannot be seen as to diminish the seriousness of the intrusion."

65 See par 121

66 See from par 123 were the court pointed to some of the factors that would be relevant in this regard.

67 Par 132

68 Par 133 the court remarked that is often difficult to determine the point at which an encounter becomes a detention and that this was something that even courts have struggled with. 
law. The court, however, added that the decision on this matter would "render similar conduct less justifiable" in the future. Although the police are not expected to know about conflicting case law, they are expected to know what the law is. ${ }^{69}$

As far as the second avenue of inquiry is concerned, the court must decide whether admission of the evidence would bring the administration of justice into disrepute from the perspective of society's interest in respect for Charter rights. ${ }^{70}$ The inquiry therefore focuses on the accused's protected interests, which in this case are two-fold:

The accused's liberty interest was firstly violated by his arbitrary detention. The court was of the opinion that although the detention did not involve any physical coercion and was not carried out in an abusive manner, the impact of the violation, though not severe, was more than minimal. The second interest violated was the accused's right to counsel. From the facts is was clear that the accused's incriminating statements were prompted by Gomes, and the accused, in need of legal advice, was not told he could consult a lawyer. The investigating officers also testified that they would not have searched the accused, but for his self-incriminatory statements. They would also not have had any legal grounds to do so. This made the evidence nondiscoverable and worsened the impact on the accused's interest in being able to make an informed choice to talk to the police. The court came to the conclusion that the impact on the mentioned rights was significant. ${ }^{7}$

As far as the final inquiry is concerned, namely the effect of admitting the gun as evidence based on the public interest, the court pointed out that the gun was highly reliable evidence and that this was essential to a determination on the merits. ${ }^{72}$ The court was of the opinion that this factor was not of much assistance in this case. On the one hand the state argued that the seriousness of the offence weighed in favour of admitting the evidence of the gun and that gun crime is a "societal scourge" that raised major public safety concerns. On the other hand the accused argued that the seriousness of the offence made it all the more important that his rights be respected. It is agreed with the court that the seriousness of an offence is a neutral factor as far as the third avenue of inquiry is concerned. ${ }^{73}$ The focus of a constitutionally entrenched exclusionary rule should indeed be on the long-term repute of the criminal justice system and not on immediate reaction to an individual case.

The court concluded by stating that the balancing test in section 24(2) was qualitative in nature and therefore not capable of mathematical precision. ${ }^{74}$ The impact of the violation on the accused's Charter protected rights weighed heavily in favour of excluding the gun, but the public interest in the adjudication of the case on its merits weighed strongly in favour of its

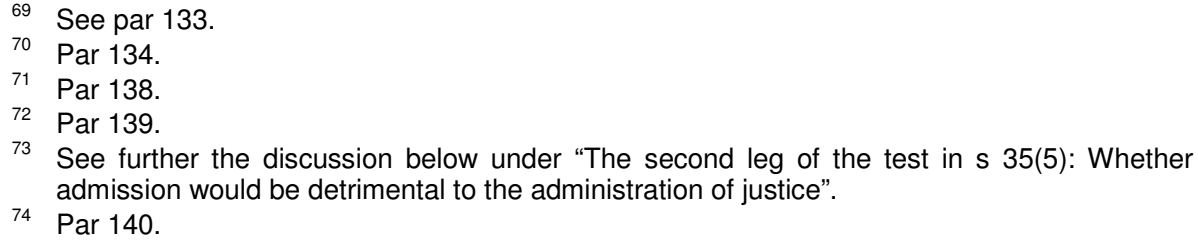


admission. The court, however, pointed out that the police officers in this case were operating in circumstances of considerable legal uncertainty, and that this fact tipped the balance in favour of admission of the gun as evidence. The repute of the justice system would therefore not have suffered from allowing the gun to be admitted in evidence.

\section{4

$\begin{array}{lll}\text { SOUTH AFRICAN } & \text { APPROACH TO THE } \\ \text { EXCLUSION OF ONCONSTITUTIONALLY }\end{array}$

\section{General}

South African courts have interpreted section 35(5) along Canadian lines, but have apparently steered away from a strict or narrow interpretation of section 35(5). The first part of the rule indicates that a causal relationship between a Bill of Rights violation and the obtaining of the evidence must be established before a court will consider whether to exclude evidence in terms of this section. ${ }^{75}$ Once such a causal link has been established, the court must then consider whether admission of the evidence would render the trial unfair (the first leg of the test) ${ }^{76}$ or whether admission would otherwise be detrimental to the administration of justice (the second leg of the test). ${ }^{77}$ Although there is over-lapping between the two legs, they are kept separate. Steytler remarks about the test in section 35(5) that: ${ }^{78}$

"It should be noted that there is principally one test - whether the admission of evidence would be detrimental to the administration of justice. The test relating to the fairness of the trial is a specific manifestation of this broader enquiry; to have an unfair trial is demonstrably detrimental to the administration of justice. Having said this, it should be emphasized that section 35(5) has created two tests which should be kept separate; rules applicable to one are not necessarily applicable to the other."

Schwikkard and Van der Merwe ${ }^{79}$ point out that in order to establish whether admission of unconstitutionally obtained evidence would have one of the undesirable consequences, a court must make a value judgment ${ }^{80}$ that takes all the facts of a specific case into account. This includes fair trial principles and considerations of public policy. In $S \vee T_{a n d w a}^{81}$ it was said that:

"The notable feature of the Constitution's specific exclusionary provisions is that it does not provide for automatic exclusion of unconstitutionally obtained evidence. Evidence must be excluded only if it (a) renders the trial unfair; or

(b) is otherwise detrimental to the administration of justice. This entails that

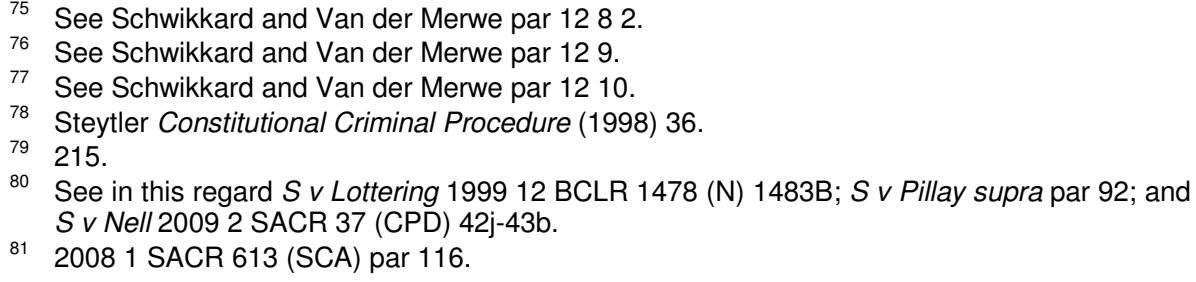


admitting impugned evidence could damage the administration of justice in ways that would leave the fairness of the trial intact: but where admitting the evidence renders the trial itself unfair, the administration of justice is always damaged. Differently put, evidence must be excluded in all cases where its admission is detrimental to the administration of justice, including the subset of cases where it renders the trial unfair. The provision plainly envisages cases where evidence should be excluded for broad public policy reasons beyond fairness to the individual accused."

\section{The first leg of the test in section 35(5): Whether admission would render a trial unfair}

Unlike the previous Canadian approach to the fair trial requirement, which had a specific meaning and content, the fair trial requirement in section 35(5) has been interpreted to be more flexible. Schwikkard and Van der Merwe note: $: 3$

"'[N]otions of basic fairness and justice', must be applied with reference to the facts of the case and have an inherent flexibility which links up neatly with the fact that s 35(5) provides a court with a discretion to determine whether the impugned evidence would render the trial unfair."

In determining whether admission of evidence would deprive the accused of his or her constitutional right to a fair trial, the court has a discretion that must be exercised on the basis of the facts of each case and by taking into account considerations such as the nature and extent of a constitutional breach, the presence or absence of prejudice to the accused, the interest of society and, also, public policy ${ }^{84}$ In this context the right to a fair trial cannot

82 In S v Mthembu 20082 SACR 407 (SCA) par 26 Cachalia JA explains that public policy in this context: "[l]s concerned not only to ensure that the guilty are held accountable; it is also concerned with the propriety of the conduct of investigating and prosecutorial agencies in securing evidence against criminal suspects. It involves considering the nature of the violation and the impact that evidence obtained as a result thereof will have, not only on a particular case, but also on the integrity of the administration of justice in the long term ... Public policy therefore sets itself firmly against admitting evidence obtained in deliberate or flagrant violation of the Constitution. If on the other hand the conduct of the police is reasonable and justifiable, the evidence is less likely to be excluded - even if obtained through an infringement of the Constitution."

83 Par 1294

84 See Schwikkard and Van der Merwe par 129 3. In S v Dzukuda; S v Thilo 20002 SACR 443 (CC) par 9-10 the Constitutional Court gives a succinct exposition of the general right to a fair trial by stating that the right to a fair trial is a comprehensive and integrated right and that the content thereof will be established on a case by case basis. Although it is possible to specify certain elements inherent to the right to a fair trial (see s 35(3) of the Constitution), it may also contain certain unspecified elements. The court explains: "An important aim of the right to a fair trial is to ensure adequately that innocent people are not wrongly convicted, because of the adverse effects which a wrong conviction has on the liberty, and dignity (and possible other) interests of the accused. There are, however, other elements of the right to a fair trial such as, for example, the presumption of innocence, the right to free legal representation in given circumstances, a trial in public which is not unreasonably delayed, which cannot be explained exclusively on the basis of averting a wrong conviction, but which arise primarily from considerations of dignity and equality." Also see S v Zuma 19951 SACR 568 (CC) par 16, where it is said that the right to a fair trial 'embraces a concept of substantive fairness' and that it is up to the criminal courts 'to give content' to the basic fairness and justice that underly a fair trial. 
be interpreted in the abstract, but must be applied in a factual context. ${ }^{85}$ In $S$ $v$ Tandwa $^{86}$ it was said that when considering the exclusion of unconstitutionally obtained evidence, the relevant factors for purposes of determining trail fairness would include:

"[T] he severity of the rights violation and the degree of prejudice, weighed against the public policy interest in bringing criminals to book. Rights violations are severe when they stem from the deliberate conduct of the police or are flagrant in nature ... There is a high degree of prejudice when there is a close causal connection between the rights violation and the subsequent selfincriminating acts of the accused ... Rights violations are not severe, and the resulting trial not unfair, if the police conduct was objectively reasonable and neither deliberate nor flagrant."

As was the previous position in Canada, trial fairness is closely linked to the privilege against compelled self-incrimination. ${ }^{87}$ Self-incriminating testimonial communications that are obtained in violation of the provisions that ensure the protection of this and other related rights were, however, never subject to automatic exclusion in the absence of an "independent source" or inevitable discovery. ${ }^{88} \mathrm{~A}$ court has a discretion in this regard and must make a value judgment that depends on the facts of each case.

As far as incriminating non-communicative real evidence obtained from the body of the accused is concerned, our courts have held that the privilege against self-incrimination is confined to testimonial communications (statements or pointings out) and that it does not extend to real evidence emanating from an accused. ${ }^{89}$ Such evidence will therefore also not be subject to automatic exclusion in the absence of an "independent source" or inevitable discovery. Although it does not affect the fairness of a trial in the sense of being an infringement involving self-incrimination, such evidence

85 In Key v Attorney-General, Cape Provincial Division 19962 SACR 113 (CC) par 13 Kriegler $J$ states that: "In any democratic criminal justice system there is a tension between, on the one hand, the public interest in bringing criminals to book and, on the other, the equally great public interest in ensuring that justice is manifestly done to all, even those suspected of conduct which would put them beyond the pale. To be sure, a prominent feature of that tension is the universal and unceasing endeavour by international human rights bodies, enlightened legislatures and courts to prevent or curtail excessive zeal by State agencies in the prevention, investigation or prosecution of crime ... But none of that means sympathy for crime and its perpetrators. Nor does it mean a predilection for technical niceties and ingenious legal stratagems. What the Constitution demands is that the accused be given a fair trial. Ultimately, as was held in Ferreira $v$ Levin, fairness is an issue which has to be decided upon the facts of each case, and the trial Judge is the person best placed to take that decision ... At times fairness might require that evidence unconstitutionally obtained be excluded. But there will also be times when fairness will require that evidence, albeit obtained unconstitutionally, nevertheless be admitted."

86 Par 117.

87 See Schwikkard and Van der Merwe par 1294 for a discussion in this regard.

88 See the discussion above under "The first group of factors in s 24(2): Factors affecting the right to a fair trial".

89 See Schwikkard and Van der Merwe par 1296 for a discussion. In this regard our courts have followed the approach stipulated in $R v$ Collins supra. For thought provoking comments as far as DNA evidence is concerned - see Biancamano "Arresting DNA: The Evolving Nature of DNA Collection Statues and their Fourth Amendment Justifications" 20093 OhioStLJ 619. 
could, however, be excluded after considering the second leg of the test in section 35(5), that is by asking whether admission would otherwise be detrimental to the administration of justice.

In a situation where real evidence is discovered on the basis of information contained in a testimonial communication unconstitutionally obtained from an accused, there is the issue of whether considerations of self-incrimination should arise at all, since the real evidence has an independent existence and possesses an objective reliability. The fact remains, however, that the compelled participation of the accused was necessary to discover the real evidence. ${ }^{90}$ It is submitted that it is unnecessary to decide whether self-incrimination is implicated or not and there should be no difference to the previous examples. There can be no automatic exclusion of such evidence in the absence of an "independent source" or inevitable discovery and the court must retain a discretion. ${ }^{9}$

The fact that trial fairness is no longer a corner stone of the Canadian test for the exclusion of unconstitutionally obtained evidence does not impact on the value of future Canadian decisions in this regard. In effect it has actually brought the application of their test closer to the South African interpretation of the trial fairness element in our test. Trial fairness is a broad concept that cannot have a specific meaning or content. This does not mean, however, that it cannot serve as a useful guide in determining whether unconstitutionally obtained evidence must be excluded.

90 In $S$ v Tandwa supra the court notes (par 125): "Furthermore, focusing, as the High Court did, on the classification of the evidence (distinguishing between the nature of the evidence - testimonial or real) is misleading, since the question should be whether the accused was compelled to provide the evidence. As the Supreme Court of Canada noted in $R v$ Stillman: "What has come to be referred to as 'real' evidence will not necessarily fall into the 'nonconscriptive' category. There is on occasion a misconception that 'real' evidence, referring to anything which is tangible and exists as an independent entity, is always admissible ... the concept of 'real' evidence without any further description is misleading. It will be seen that, in certain circumstances, evidence such as the gun ... may come into the state's possession as a result of the accused's compelled participation or 'conscription' against himself. Thus, while the evidence is 'real' it is nevertheless conscriptive evidence."

91 As far as the issue of derivative evidence arising from compelled self-incrimination is concerned, South African courts have laid down no absolute rules. In Ferreira $v$ Levin NO Vryenhoek $v$ Powell NO 19961 BCLR 1 (CC) Ackermann J, in dealing with certain provisions of the interim Constitution, said (par 153): "A compulsion to give self-incriminating evidence, coupled with use of immunity along the lines indicated above, and subject to a judicial discretion to exclude derivative evidence at the trial, would not negate the essential content of ... the s 25(3) right to a fair trial. ... As far as s 25(3) is concerned, the trial Judge is obliged to ensure a 'fair trial', if necessary by his or her discretion to exclude, in the appropriate case, derivative evidence. Ultimately this is a question of fairness to the accused and is an issue which has to be decided on the facts of each case. The trial Judge is the person best placed to take that decision. The development of the law of evidence in this regard is a matter for the Supreme Court. The essential content of the right is therefore not even touched." See Schwikkard and Van der Merwe par 1297 for a discussion of the factors that will be relevant in deciding whether to exclude derivative evidence. 


\section{The second leg of the test in section 35(5): Whether admission would be detrimental to the administration of justice}

The second leg of the test is the final filter when considering whether to exclude unconstitutionally obtained evidence. ${ }^{92}$ Where the admission of evidence would not render the trial unfair, it must nevertheless be excluded if the court is satisfied that admission would be detrimental to the administration of justice. In $S \vee$ Mphala $^{93}$ Cloete $\mathrm{J}$ said the following about the second leg of the test in section 35(5):

"So far as the administration of justice is concerned, there must be a balance between, on the one hand, respect (particularly by law enforcement agencies) for the Bill of Rights and, on the other, respect (particularly by the man on the street) for the judicial process. Overemphasis of the former would lead to acquittals on what would be perceived by the public as technicalities, whilst overemphasis of the latter would lead at best to a dilution of the Bill of Rights and at worst to its provisions being negated."

In trying to strike a balance, the court may take a variety of factors and considerations into account, but must ultimately ensure that, on the facts of each case, the admission of unconstitutionally obtained evidence is not detrimental to the administration of justice. A full discussion of these factors is beyond the scope of this comment, ${ }^{95}$ but it is submitted that the Canadian Supreme Court's approach in $R v$ Grant $^{96}$ provides a very useful and wellstructured break-up of the relevant factors to consider. It is, however, necessary to look at one important consideration, namely the influence that public opinion should have on a court's decision in this regard. What role should public acceptance of a decision to exclude unconstitutionally obtained but highly incriminating evidence play? And also, should the high crime rate in South Africa have any influence on a court's decision? ${ }^{97}$

Some writers are of the opinion that, despite the long-term values which the Constitution seeks to secure, ${ }^{98}$ the prevailing public opinion is an

92 See Schwikkard and Van der Merwe par 1210.

9319981 SACR 388 (W) 657g-h.

94 This approach was cited with approval by the Supreme Court of Appeal in $S v$ Tandwa supra par 118; and in $S$ v Pillay supra 447i-j.

95 See Schwikkard and Van der Merwe par 1210 in this regard.

96 Supra.

97 In S v Ngcobo 199810 BCLR 1248 (N) 1254G, Combrinck J remarks about the exclusion of incriminating evidence: "At best of times but particularly in the current state of endemic violent crime in all parts of our country it is unacceptable to the public that such evidence be excluded. Indeed the reaction is one of shock, fury and outrage when a criminal is freed because of the exclusion of such evidence."

98 Compare S v Makwanyane 19953 SA 391 (CC) par 88 where the Constitutional Court stated that, in considering the constitutional validity of the death penalty, public opinion is "no substitute for the duty vested in the Courts to interpret the Constitution and to uphold its provisions without fear or favour". Schwikkard and Van der Merwe 250 is of the opinion that there is a big difference between the role of public opinion in determining the constitutional validity of a particular sentence and the role of public opinon in deciding whether to exclude unconstitutionally obtained evidence. It is, however, submitted that there is not such a big difference at all. 
important factor to consider under the second leg of the test in section 35(5) of the Constitution. ${ }^{99}$ It is submitted, however, that public opinion is a neutral factor in this regard. ${ }^{100}$ An important focus of section 35(5) is the long-term repute of the criminal justice system. The public may have an interest in seeing a case decided on its merits, but it has an even bigger interest in a criminal justice system that is beyond reproach. In $S v$ Tandwa $^{101}$ the court remarks:

"[l]n this country's struggle to maintain law and order against the ferocious onslaught of violent crime and corruption, what differentiates those committed to the administration of justice from those who would subvert it is the commitment of the former to moral ends and moral means. We can win the struggle for a just order only through means that have moral authority. We forfeit that authority if we condone coercion and violence and other corrupt means in sustaining order. Section $35(5)$ is designed to protect individuals from police methods that offend basic principles of human rights."

The notion that systemic (or general) deterrence is the primary goal of the exclusionary rule is therefore supported. ${ }^{103}$ Dressler and Michaels ${ }^{104}$ succinctly capture the essence of this view:

"The exclusionary rule is meant to deter unconstitutional police conduct by promoting professionalism within the ranks, specifically by creating an incentive for police departments to hire individuals sensitive to civil liberties, to better train officers in the proper use of force, to keep officers updated on constitutional law, and to develop internal guidelines that reduce the likelihood of unreasonable arrests and searches."

The public may find it repulsive to see reliable evidence being excluded, but it is rather the government officials that violated the constitutionally entrenched rights that must be held accountable for this outcome. Steytler ${ }^{105}$ points out that the exclusionary rule pursues the same purposes as the general remedy clause: it aims to vindicate a violation of a constitutional right and also intends to deter and prevent the recurrence of the infringement. The reliability of evidence is no longer the driving force behind its

99 Also see the opinion expressed by Scott JA in a minority judgment given in $S$ v Pillay supra 448a-d.

100 Compare the remarks made by the majority in $R v$ Grant supra par 84.

101 Supra 649f-g.

102 See also S v Coetzee 19974 BCLR 437 (CC) par 220 where Sachs J notes (in the context of the limitation clause): "There is a paradox at the heart of all criminal procedure, in that the more serious the crime and the greater the public interest in securing convictions of the guilty, the more important the constitutional protections of the accused become."

103 See generally Naudé "The Inclusion of Inevitably Discoverable Evidence" 20082 SACJ 168 181. Compare Mertens and Wasserstrom "The Good Faith Exception to the Exclusionary Rule: Deregulating the Police and Derailing the Law" 198170 GeoLJ 365394 . See also the opinion of Brennan $\mathrm{J}$ where he remarks in a dissenting opinion in the case of US $v$ Leon 468 US 897 (1984) 953: "[T]he chief deterrent function of the rule is its tendency to promote institutional compliance with Fourth Amendment requirements on the part of law enforcement agencies generally." For recent sentiments in this regard - see AZ Lipson "The Good Faith Exception as Applied to Illegal Predicate Searches: A Free Pass to Institutional Ignorance" (2009) 5 HastingsLJ 1147.

104378.

10534. 
admissibility, since the Constitution has made "the rights of the individual and the fairness and integrity of the judicial system paramount".

\section{CONCLUSION}

The approach to the exclusion of unconstitutionally obtained evidence set out by the Canadian Supreme Court in $R \vee$ Grant $^{107}$ has corrected the shortcomings of their previous approach. The new test, being less rigid and more simplistic, properly reflects the main purposes behind a constitutionally entrenched exclusionary rule and thereby provides a sound theoretical basis for the application of such a rule. Because the application of section 24(2) of the Canadian Charter of Rights and Freedoms has now been brought closer to the application of the test embodied in section 35(5) of the Constitution, future Canadian decisions will provide more useful insight into how our courts should approach difficult issues concerning the exclusion of unconstitutionally obtained evidence. Perhaps the most important aspect of the Grant decision is that it shows why it is unnecessary to consider the two legs in the South African rule as separate tests. In principle there should be only one test - namely whether the admission of certain evidence would be detrimental to the administration of justice. By focussing on the seriousness of the Bill of Rights-infringing conduct, the impact on the Bill of Rightsprotected interests of the accused and on society's interest in a decision on the merits, both the right to a fair trial and the detriment of the administration of justice are fully considered.

${ }^{106}$ See $R$ v Burlingham 199597 CCC (3d) 385 (SCC) par 39.

107 Supra. 